\title{
The Role of Overweight and Obesity in the Cardiorenal Syndrome
}

\author{
James R. Sowers ${ }^{\mathrm{a}-\mathrm{d}} \quad$ Adam Whaley-Connell ${ }^{c, d}$ \\ Melvin R. Hayden ${ }^{c}$ \\ aDivision of Endocrinology, Diabetes and Metabolism, Department of Internal Medicine, \\ ${ }^{b}$ Department of Medical Pharmacology and Physiology, University of Missouri-Columbia \\ School of Medicine, ${ }^{c}$ Diabetes and Cardiovascular Center, and ${ }^{d}$ Harry S. Truman VA Medical \\ Center, Columbia, Mo., USA
}

\section{Key Words}

Adiposity $\cdot$ Cardiorenal metabolic syndrome $\cdot$ Chronic kidney disease $\cdot$ Heart failure $\cdot$

Metabolic dyslipidemia • Obesity

\begin{abstract}
The presence of a group of interactive maladaptive factors including hypertension, insulin resistance, metabolic dyslipidemia, obesity, microalbuminuria, and/or reduced renal function constitute the cardiorenal metabolic syndrome (CRS). Overweight, obesity, and chronic kidney disease (CKD) have grown to pandemic proportions in industrialized countries during the past decade. The fact that these interactive factors promote heart and renal disease has been documented in large population-based studies. Obesity seems to be the driving force behind the development of heart disease and CKD and therefore the CRS. The relationship between overweight/obesity and kidney disease begins in early childhood and appears to be related to overconsumption of high-fructose corn syrup and insufficient physical activity. Today, 13 million children are obese, and over $70 \%$ of these children are likely to become obese adults. Indeed, approximately $30 \%$ of male and $34 \%$ of female adults in the United States are obese. This lifestyle-related epidemic will be a major societal medical and economic problem that will accentuate the current epidemic of CKD in the United States and other industrialized and emerging industrialized countries. In this article, we will review the potential mechanisms by which obesity and other metabolic abnormalities interact to promote heart and progressive kidney disease.




\section{CardioRenal \\ Medicine}

\begin{tabular}{l|l}
\hline Cardiorenal Med 2011;1:5-12 \\
\hline $\begin{array}{l}\text { DOI: 10.1159/000322822 } \\
\text { Published online: January 17, 2011 }\end{array}$ & $\begin{array}{l}\text { @ } 2011 \text { S. Karger AG, Basel } \\
\text { www.karger.com/crm }\end{array}$ \\
\hline
\end{tabular}

Sowers et al.: Obesity and Chronic Kidney Disease

\section{Introduction}

Overweight and obesity occur in $>72$ million American adults [1-4]. This epidemic is associated with increased cardiovascular- and renal-disease-related morbidity and mortality [3, 4]. Childhood-adolescent overweight and obesity are emerging major global public health concerns [6-11]. Since 1980 obesity rates in children have tripled. Currently, 13 million children in the United States are obese, including 14\% of all 6- to 11-year-old children and 17\% of adolescents [6]. The international Obesity Task Force has estimated that 22 million children younger than 5 years are overweight or obese [7]. They have also estimated that 1 in 10 children, approximately 155 million, are overweight. Additionally, about 3\% of children aged 5-17 years are now classified as obese (approximately 45 million of the 155 million). This emerging pandemic is largely thought to be triggered by the same sociologic/environmental factors that have resulted in two thirds of adults in this country being overweight or obese [6-15]. These driving forces for overweight and obesity in children, as well as adults, include increasing sedentary lifestyles with physical inactivity and excess compact caloric consumption. Childhood-adolescent overweight is defined as a body mass index (BMI) greater than the 85th percentile but less than the 95th percentile, whereas childhood-adolescent obesity is defined as a BMI greater than the 95th percentile [8]. Childhood obesity is associated with an increased prevalence (up to 50\%) of the metabolic (cardiorenal) syndrome; the prevalence is increased on a graded scale based on increasing BMI [9]. Childhood obesity is also the most common cause of insulin resistance (IR), which is associated with dyslipidemia, long-term cardiovascular complications, including hypertension, pre-diabetes (impaired glucose tolerance), fatty liver disease, and overt type 2 diabetes mellitus [10,11].

Childhood obesity and associated medical problems such as chronic kidney disease (CKD) are more prevalent in minority and socioeconomically deprived children and adults [16-21]. These disparities are also evidenced in the increased prevalence of diabetes and hypertension in these populations $[17,18]$. Importantly, childhood obesity is also associated with increased inflammation, with elevated levels of inflammatory biomarkers, including C-reactive protein, interleukin- 6 , and tumor necrosis factor- $\alpha$, and decreased levels of adiponectin, a marker of insulin sensitivity synthesized and secreted exclusively by adipocytes $[4,5,7]$. These factors all contribute to the increasingly recognized relationship between obesity and the early development of childhood/adolescent kidney disease and diabetes, and underscore the importance of emerging interventions to prevent the development of these chronic diseases [7, 11-15].

\section{Cardiorenal Metabolic Syndrome and the Epidemic of CKD}

As suggested in the preceding information, the presence of a constellation of interactive cardiac and renal risk factors, including overweight/obesity, hypertension, IR/hyperinsulinemia, metabolic dyslipidemia, microalbuminuria and/or reduced renal function, constitute the cardiorenal metabolic syndrome (CRS) in both children and adults (table 1, fig. 1) [22]. For example, in 19,096 non-diabetic persons in the Atherosclerosis Risk in Communities (ARIC) study, the odds ratio for developing CKD in those with CRS compared to those without the syndrome was 1.43 [23]. Likewise, in a cohort of 320,252 adults followed over a 15- to 35-year period, the rate of end-stage renal disease (ESRD) increased in a fashion proportional to BMI [24]. Increasing components of the syndrome progressively enhance the risk for microalbuminuria [25] and proteinuria [26]. In this regard, the association between components of the conventional metabolic syndrome and the risk for both microalbuminuria and CKD was evaluated in the Third National Health and Nutrition Examination Survey (NHANES III) [25]. In multivariant adjusted analysis, the odds ratio for microalbuminuria and CKD was 1.89 and 2.60, respectively. Additionally, the risk for microalbuminuria 


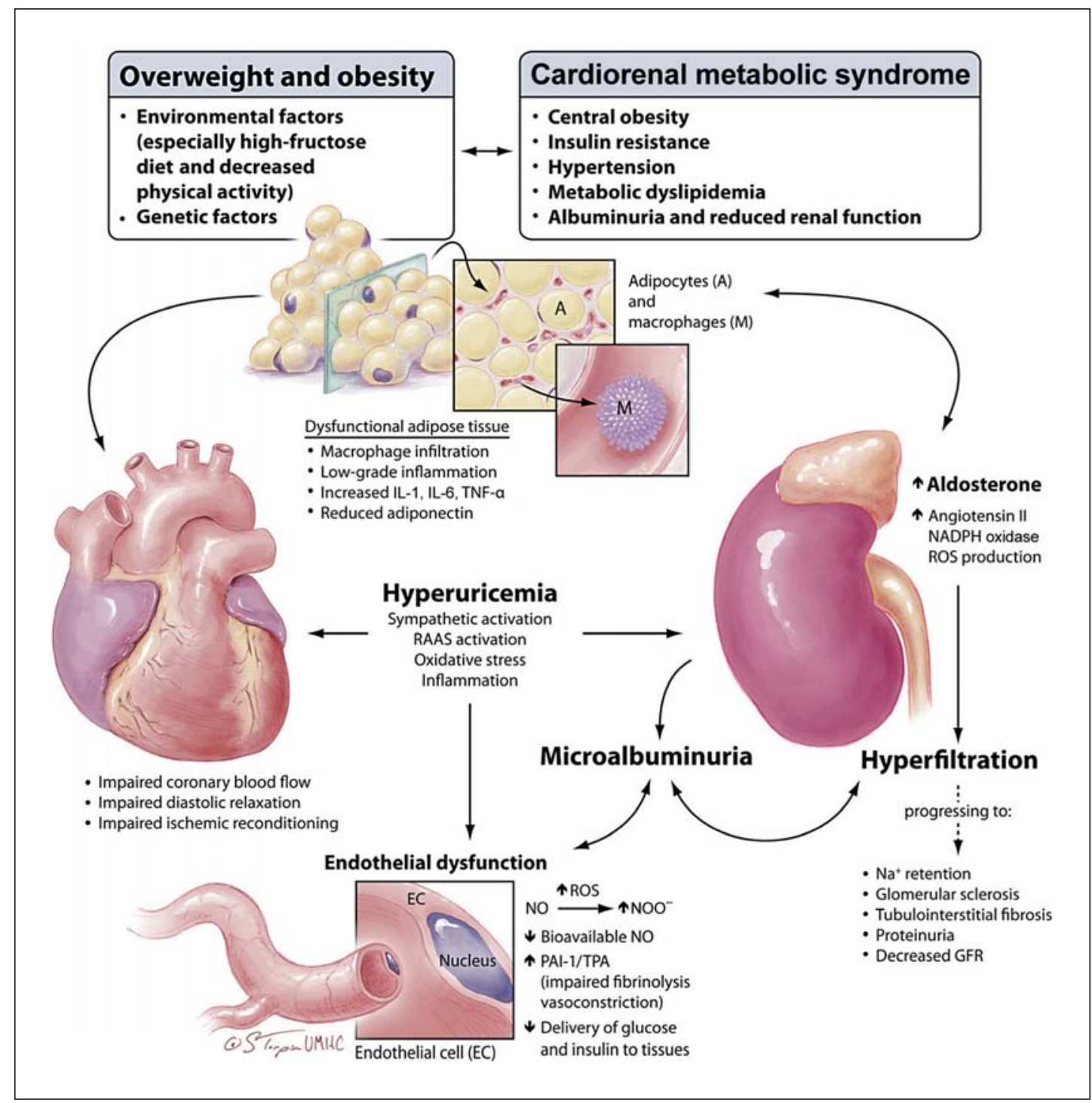

Fig. 1. The interrelationship between adiposity and maladaptive changes in the heart and kidney in CRS. GFR = Glomerular filtration rate; $\mathrm{IL}=$ interleukin; $\mathrm{PAI}=$ plasminogen activator inhibitor; $\mathrm{RAAS}=$ reninangiotensin-aldosterone system; ROS = reactive oxygen species; TNF = tumor necrosis factor; $\mathrm{TPA}=$ tis sue plasminogen activator.

Table 1. CRS components

Central obesity

Insulin resistance

Hypertension

Metabolic dyslipidemia (low HDL, high triglycerides and increased small, dense LDL particles)

Albuminuria

Reduced glomerular filtration rate $(<60 \mathrm{ml} / \mathrm{min})$ 


\section{CardioRenal \\ Medicine}

\begin{tabular}{l|l}
\hline Cardiorenal Med 2011;1:5-12 \\
\hline $\begin{array}{l}\text { DOI: 10.1159/000322822 } \\
\text { Published online: January 17, 2011 }\end{array}$ & $\begin{array}{l}\text { @ } 2011 \text { S. Karger AG, Basel } \\
\text { www.karger.com/crm }\end{array}$ \\
\hline
\end{tabular}

Sowers et al.: Obesity and Chronic Kidney Disease

and CKD was proportional to the number of individual components present. In a Japanese population, similar data on the impact of components of the metabolic syndrome and CKD were documented in men younger than 60 years $[26,27]$. There are mounting data that support a relationship between dysglycemia and other components of the CRS and CKD independent of the presence of clinical diabetes [28-30].

There is accumulating evidence that overweight/obesity is the driving force for this syndrome [22, 31-37]. To this point, the relationship between BMI and ESRD was observed in a Japanese population of over 100,000 persons followed for 17 years [32]. Indeed, the cumulative incidence of ESRD increased significantly with rising BMI after adjustment for age, systolic blood pressure, and proteinuria. The interaction between obesity and other renal-disease-promoting factors has been partly elucidated by several observational and mechanistic studies [32-49]. One of the potential mechanisms by which obesity promotes CKD is through hyperfiltration-related maladaptive mechanisms [32-49]. Our understanding of the role of obesity and related metabolic factors in promoting renal disease has been advanced by a number of studies conducted recently. In one study [32], investigators phenotyped 1,572 young men (mean age 18.4 years) for metabolic risk factors, and renal function was ascertained by calculated creatinine clearance based on the Cockcroft-Gault equation. These investigators reported that metabolic risk clustering of three or more risk factors was strongly associated with glomerular hyperfiltration. This early renal functional abnormality was especially associated with adiposity (elevated leptin levels and anthropometric determinants) and elevated blood pressure. Based on these data, the authors proposed that increased adiposity, particularly visceral fat production of inflammatory adipokines, was a major driving force of glomerular hyperfiltration.

Glomerular hyperfiltration in humans has been hypothesized to reflect increased glomerular capillary pressure, which is a seminal mediator of glomerular capillary damage in rodent models [22,37]. In this regard, investigators have recently reported the prevalence of hyperfiltration in 301 non-diabetic adults of African ancestry [36]. The prevalence of glomerular hyperfiltration, defined as an insulin clearance rate $>140 \mathrm{ml} / \mathrm{min}$, was threefold higher (27 vs. $7 \%$ ) among obese participants (BMI >30) compared to lean participants (BMI $<25$ ). Obese participants also had higher effective renal plasma blood flow estimated by para-aminohippuric acid clearance. These obesity-related early renal functional changes may be especially detrimental in populations manifesting lower birth weights and lower nephron numbers [16-20, 31-35]. Other factors, such as systemic and renal inflammation and oxidative stress [22], may determine to what extent this hyperfiltration translates into glomerular and tubulointerstitial fibrosis and progressive renal disease.

Obesity, CRS and CKD epidemics in the United States have paralleled the substantially increased consumption of high-fructose corn syrup (HFCS) [50]. Indeed, HFCS consumption has increased dramatically in the past 3 decades. HFCS currently represents $40 \%$ of the non-calorie-free sweeteners in food in the United States. Sweetened beverages, such as nondiet soda, account for $70 \%$ of the intake of HFCS [50]. Recent investigations have shown that HFCS-sweetened soda consumption is associated with albuminuria [51] and elevated serum creatinine [48]. One of the possible mechanisms by which increased HFCS consumption causes renal disease is through increases in uric acid production. The metabolism of fructose increases the degradation of nucleotides and the associated synthesis of uric acid [43, 52]. In rodent models, fructose-associated hyperuricemia produces CRS with glomerular hyperfiltration, renal hypertrophy, and arteriolopathy of the renal vasculature, and subsequent increases in proteinuria and reductions in creatinine clearance (fig. 1) [43-46].

Hyperinsulinemia can reduce renal excretion of uric acid as insulin can stimulate the urate-anion exchanger and/or the sodium-dependent anion co-transporter in brush border membranes of the renal proximal tubule and increase urate reabsorption [43]. 


\section{CardioRenal \\ Medicine}

\begin{tabular}{l|l}
\hline Cardiorenal Med 2011;1:5-12 \\
\hline DOl: 10.1159/000322822 & $\begin{array}{l}\text { @ } 2011 \text { S. Karger AG, Basel } \\
\text { www.karger.com/crm }\end{array}$ \\
\hline Published online: January 17, 2011
\end{tabular}

Sowers et al.: Obesity and Chronic Kidney Disease

Recently, a relationship between sugar-sweetened soda consumption and hyperuricemia and kidney disease was evidenced from an analysis of data from the ARIC study [50]. Compared to participants who drank less, consumption of more than one soda per day was associated with increased odds of prevalent hyperuricemia and CKD. The odds ratio for CKD significantly increased to 2.59 among participants who drank more than one soda per day and had a serum uric acid $>9.0 \mathrm{mg} / \mathrm{dl}$. Indeed, stratified analysis indicated that the association between intake of sweetened beverages and declining renal function was primarily found among participants with elevated serum uric acid levels. As noted by the investigators, these findings are in accordance with prior publications reporting that high-sugar-sweetened soda consumption was associated with prevalent hyperuricemia and renal injury [4852]. The authors further suggested that this supports other data indicating that increased intake of sugar-sweetened soda may be the driving force for the epidemic of obesity, hypertension, CRS, and diabetes [53-55].

\section{CRS and Heart Disease}

Heart failure (HF) is present in $>5$ million persons in the United States, accounting for nearly 40 billion US dollars in annual health care costs [56]. The most common form of HF is that with preserved ejection fraction, and it is increasing in westernized cultures [57]. Both overweight/obesity and aging are prominent risk factors for this form of $\mathrm{HF}[56,57]$, and they are associated with higher rates of hypertension and diabetes $[3,4]$, which also contribute to an increase in HF with preserved systolic function. Obesity is associated with a metabolic cardiomyopathy, which is characterized by impaired left ventricular relaxation, usually in association with IR [58-60]. In this metabolic form of heart disease, relaxation abnormalities usually occur before the onset of contractile dysfunction [58-60]. Diastolic dysfunction is characterized by a diminution in the ability of the left ventricle to fill with blood during early diastolic filling $[60,61]$.

IR appears to play an important role in obesity-related HF. Impaired insulin metabolic signaling, reduced bioavailable nitric oxide (NO), and increased generation of reactive oxygen species, all play a role in maladaptive remodeling, interstitial fibrosis and impaired diastolic relaxation [60, 62-69]. Hyperuricemia may contribute to this maladaptation as it causes increases in reactive oxygen species, reduces bioavailable NO, and promotes endothelial dysfunction [43]. Strategies to prevent and treat metabolic heart disease, especially in the presence of associated kidney disease, include lifestyle changes (weight reduction and exercise) and medical therapies that reduce oxidative stress and improve bioavailable $\mathrm{NO}$ and insulin metabolic signaling $[60,70]$.

\section{Conclusion}

The association of overweight/obesity, CKD, and HF with preserved systolic function has spawned an epidemic in industrialized countries. We refer to this constellation of diseases as the cardiorenal metabolic syndrome, which is an extension of the prior use of this terminology to refer to coexistent heart and kidney disease. The current use of this terminology considers obesity, especially central obesity, as a pivotal factor in the development of IR, metabolic dyslipidemia, and associated kidney and heart disease. This syndrome is becoming an epidemic, largely because of the high prevalence of overweight/obesity in industrialized countries. We have revised underlying mechanistic and epidemiological factors that promote kidney and heart disease in concert with the development of metabolic components of the syndrome. 


\section{CardioRenal Medicine}

\begin{tabular}{l|l}
\hline Cardiorenal Med 2011;1:5-12 \\
\hline $\begin{array}{l}\text { DOI: 10.1159/000322822 } \\
\text { Published online: January 17, } 2011\end{array}$ & $\begin{array}{l}\text { @ 2011 S. Karger AG, Basel } \\
\text { www.karger.com/crm }\end{array}$ \\
\hline
\end{tabular}

Sowers et al.: Obesity and Chronic Kidney Disease

\section{Acknowledgments}

The authors would like to acknowledge Stacy Turpin for her illustration and Brenda Hunter for her assistance with this paper. This research was supported by NIH (R01 HL73101-01A1), Veterans Affairs Merit System 0018 (J.R.S.).

\section{References}

1 Ogden CL, Carroll MD, Curtin LR, McDowell MA, Tabak CJ, Flegal KM: Prevalence of overweight and obesity in the United States, 1999-2004. JAMA 2006;295:1549-1555.

-2 McGee DL, Diverse Populations Collaboration: Body mass index and mortality: a meta-analysis based on personlevel data from twenty-six observational studies. Ann Epidemiol 2005;15:87-97.

-3 Ghandehari H, Le V, Kamal-Bahl S, Bassin SL, Wong ND: Abdominal obesity and the spectrum of global cardiometabolic risks in US adults. Int J Obes (Lond) 2009;33:239-248.

4 Sowers JR: Obesity as a cardiovascular risk factor. Am J Med 2003;115(suppl 8A):37S-41S.

5 Liese AD, Hense HW, Döring A, Stieber J, Keil V: Microalbuminuria, central adiposity and hypertension in the nondiabetic urban population of the MONICA Augsburg survey 1994/95. J Hum Hypertens 2001;15:799-804.

-6 Ogden CL, Carroll MD, Flegal KM: High body mass index for age among US children and adolescents, 2003-2006. JAMA 2008;299:2401-2405.

7 Allcock DM, Gardner JM, Sowers JR: Relation between childhood obesity and adult cardiovascular risk. Int J Pediatr Endocrinol 2009;2009:108187.

8 Hampton T: Pediatric obesity guidelines released. JAMA 2008;300:2238.

-9 Weiss R, Dziura J, Burgert TS, Tamborlane WV, Taksali SE, Yeckel CW, Allen K, Lopes M, Savoye M, Morrison J, Sherwin RS, Caprio S: Obesity and the metabolic syndrome in children and adolescents. N Engl J Med 2004;350: 2362-2374.

10 Fabbrini E, deHaseth D, Deivanayagam S, Mohammed BS, Vitola BE, Klein S: Alterations in fatty acid kinetics in obese adolescents with increased intrahepatic triglyceride content. Obesity 2008;17:25-29.

-11 Coppen AM, Risser JA, Vash PD: Metabolic syndrome resolution in children and adolescents after 10 weeks of weight loss. J Cardiometab Syndr 2008;3:205-210.

12 Fowler GC, Vasudevan DA: Type 2 diabetes mellitus: managing hemoglobin A(1c) and beyond. South Med J 2010;103: 911-916.

13 Dagenais GR, Yi Q, Mann JF, Bosch J, Pogue J, Yusuf S: Prognostic impact of body weight and abdominal obesity in women and men with cardiovascular disease. Am Heart J 2005;149:54-60.

- 14 Bakris G, Vassalotti J, Ritz E, Wanner C, Stergiou G, Molitch M, Nesto R, Kaysen GA, Sowers JR, CKD Consensus Working Group: National Kidney Foundation consensus conference on cardiovascular and kidney diseases and diabetes risk: an integrated therapeutic approach to reduce events. Kidney Int 2010;78:726-736.

15 Coresh J, Selvin E, Stevens LA, Manzi J, Kusek JW, Eggers P, Van Lente F, Levey AS: Prevalence of chronic kidney disease in the United States. JAMA 2007;298:2038-2047.

$\checkmark 16$ Lackland DT, Bendall HE, Osmond C, Egan BM, Barker DJ: Low birth weights contribute to high rates of early-onset chronic renal failure in the Southeastern United States. Arch Intern Med 2000;160:1472-1476.

$\checkmark 17$ Cruz ML, Weigensberg MJ, Huang TT, Ball G, Shaibi GQ, Goran MI: The metabolic syndrome in overweight Hispanic youth and the role of insulin sensitivity. J Clin Endocrinol Metab 2004;89:108-113.

18 Cossrow N, Falkner B: Race/ethnic issues in obesity and obesity-related comorbidities. J Clin Endocrinol Metab 2004; 89:2590-2594.

19 Ward MM: Socioeconomic status and the incidence of ESRD. Am J Kidney Dis 2008;51:563-572.

20 White SL, Perkovic V, Cass A, Chang CL, Poulter NR, Spector T, Haysom L, Craig JC, Salmi IA, Chadban SJ, Huxley RR: Is low birth weight an antecedent of CKD in later life? A systematic review of observational studies. Am J Kidney Dis 2009;54:248-261.

21 CKD major public health concerns worldwide. Further ethnic disparities - African Americans, native Americans greater rates of kidney failure as well as earlier age onset and progression than whites. International Diabetes Federation, http://www.idf.org/2009.

22 Sowers JR: Metabolic risk factors and renal disease. Kidney Int 2007;71:719-720.

23 Kurella M, Lo JC, Chertow GM: Metabolic syndrome and the risk of chronic kidney disease among nondiabetic adults. J Am Soc Nephrol 2005; 16:2134-2140.

24 Hsu CY, McCulloch CE, Iribarren C, Darbinian J, Go AS: Body mass index and the risk for end-stage renal disease. Ann Intern Med 2006;144:21-28.

25 Chen J, Muntner P, Hamm LL, Jones DW, Batuman V, Fonseca V, Whelton PK, He J: The metabolic syndrome and chronic kidney disease in U.S. adults. Ann Intern Med 2004;140:167-174.

26 Jee SH, Boulware LE, Guallar E, Suh I, Appel LJ, Miller ER 3rd: Direct, progressive association of cardiovascular risk factors with incident proteinuria: results from the Korea Medical Insurance Corporation (KMIC) study. Arch Intern Med 2005;165:2299-2304. 


\section{CardioRenal Medicine}

\begin{tabular}{l|l}
\hline Cardiorenal Med 2011;1:5-12 \\
\hline $\begin{array}{l}\text { DOI: 10.1159/000322822 } \\
\text { Published online: January 17, } 2011\end{array}$ & $\begin{array}{l}\text { @) 2011 S. Karger AG, Basel } \\
\text { www.karger.com/crm }\end{array}$ \\
\hline
\end{tabular}

Sowers et al.: Obesity and Chronic Kidney Disease

27 Tanaka H, Shiohira Y, Uezu Y, Higa A, Iseki K: Metabolic syndrome and chronic kidney disease in Okinawa, Japan. Kidney Int 2006;69:369-374.

28 Lea J, Cheek D, Thornley-Brown D, Appel L, Agodoa L, Contreras G, Gassman J, Lash J, Miller ER 3rd, Randall O, Wang X, McClellan W, AASK Study Investigators: Metabolic syndrome, proteinuria, and the risk of progressive CKD in hypertensive African Americans. Am J Kidney Dis 2008;51:732-740.

29 Lucove J, Vupputuri S, Heiss G, North K, Russell M: Metabolic syndrome and the development of CKD in American Indians: the Strong Heart Study. Am J Kidney Dis 2008;51:21-28.

-30 Whaley-Connell A, Pavey BS, McCullough PA, Saab G, Li S, McFarlane SI, Chen SC, Vassalotti JA, Collins AJ, Bakris G, Sowers JR, KEEP Investigators: Dysglycemia predicts cardiovascular and kidney disease in the Kidney Early Evaluation Program. J Clin Hypertens (Greenwich) 2010;12:51-58.

-31 Kasiske BL, Napier J: Glomerular sclerosis in patients with massive obesity. Am J Nephrol 1985;5:45-50.

-32 Iseki K, Ikemiya Y, Kinjo K, Inoue T, Iseki C, Takishita S: Body mass index and the risk of development of end-stage renal disease in a screened cohort. Kidney Int 2004;65:1870-1876.

-33 Ejerblad E, Fored CM, Lindblad P, Fryzek J, McLaughlin JK, Nyrén O: Obesity and risk for chronic renal failure. J Am Soc Nephrol 2006;17:1695-1702.

-34 Tomaszewski M, Charchar FJ, Maric C, McClure J, Crawford L, Grzeszczak W, Sattar N, Zukowska-Szczechowska E, Dominiczak AF: Glomerular hyperfiltration: a new marker of metabolic risk. Kidney Int 2007;71:816-821.

$>35$ Griffin KA, Kramer H, Bidani AK: Adverse renal consequences of obesity. Am J Physiol Renal Physiol 2008;294:F685F696.

-36 Wuerzner G, Pruijm M, Maillard M, Bovet P, Renaud C, Burnier M, Bochud M: Marked association between obesity and glomerular hyperfiltration: a cross-sectional study in an African population. Am J Kidney Dis 2010;56:303-312.

37 Levey AS, Kramer H: Obesity, glomerular hyperfiltration, and the surface area correction. Am J Kidney Dis 2010:56: $255-258$.

38 Morales E, Valero MA, León M, Hernández E, Praga M: Beneficial effects of weight loss in overweight patients with chronic proteinuric nephropathies. Am J Kidney Dis 2003;41:319-327.

-39 Chagnac A, Weinstein T, Herman M, Hirsh J, Gafter U, Ori Y: The effects of weight loss on renal function in patients with severe obesity. J Am Soc Nephrol 2003;14:1480-1486.

40 Tran HA: Reversible obesity-related glomerulopathy following weight reduction. Med J Aust 2006;184:367.

-41 Navarro-Díaz M, Serra A, Romero R, Bonet J, Bayés B, Homs M, Pérez N, Bonal J: Effect of drastic weight loss after bariatric surgery on renal parameters in extremely obese patients: long-term follow-up. J Am Soc Nephrol 2006; 17:S213-S217.

-42 Serra A, Granada ML, Romero R, Bayés B, Cantón A, Bonet J, Rull M, Alastrue A, Formiguera X: The effect of bariatric surgery on adipocytokines, renal parameters and other cardiovascular risk factors in severe and very severe obesity: 1-year follow-up. Clin Nutr 2006;25:400-408.

-43 Nakagawa T, Hu H, Zharikov S, Tuttle KR, Short RA, Glushakova O, Ouyang X, Feig DI, Block ER, Herrera-Acosta J, Patel JM, Johnson RJ: A causal role for uric acid in fructose-induced metabolic syndrome. Am J Physiol Renal Physiol 2006;290:F625-F631.

44 Bell RC, Carlson JC, Storr KC, Herbert K, Sivak J: High-fructose feeding of streptozotocin-diabetic rats is associated with increased cataract formation and increased oxidative stress in the kidney. Br J Nutr 2000;84:575-582.

-45 Sánchez-Lozada LG, Tapia E, Jiménez A, Bautista P, Cristóbal M, Nepomuceno T, Soto V, Avila-Casado C, Nakagawa T, Johnson RJ, Herrera-Acosta J, Franco M: Fructose-induced metabolic syndrome is associated with glomerular hypertension and renal microvascular damage in rats. Am J Physiol Renal Physiol 2007;292:F423-F429.

- 46 Gersch MS, Mu W, Cirillo P, Reungjui S, Zhang L, Roncal C, Sautin YY, Johnson RJ, Nakagawa T: Fructose, but not dextrose, accelerates the progression of chronic kidney disease. Am J Physiol Renal Physiol 2007;293:F1256-F1261.

47 Lee JE, Kim YG, Choi YH, Huh W, Kim DJ, Oh HY: Serum uric acid is associated with microalbuminuria in prehypertension. Hypertension 2006;47:962-967.

48 Saldana TM, Basso O, Darden R, Sandler DP: Carbonated beverages and chronic kidney disease. Epidemiology 2007; 18:501-506.

-49 Johnson RJ, Segal MS, Sautin Y, Nakagawa T, Feig DI, Kang DH, Gersch MS, Benner S, Sánchez-Lozada LG: Potential role of sugar (fructose) in the epidemic of hypertension, obesity, and the metabolic syndrome, diabetes, kidney disease, and cardiovascular disease. Am J Clin Nutr 2007;86:899-906.

50 Bomback AS, Derebail VK, Shoham DA, Anderson CA, Steffen LM, Rosamond WD, Kshirsagar AV: Sugar-sweetened soda consumption, hyperuricemia, and kidney disease. Kidney Int 2010;77:609-616.

51 Shoham DA, Durazo-Arvizu R, Kramer H, Luke A, Vupputuri S, Kshirsagar A, Cooper RS: Sugary soda consumption and albuminuria: results from the National Health and Nutrition Examination Survey, 1999-2004. PLoS One 2008; 3:e3431.

52 Choi JW, Ford ES, Gao X, Choi HK: Sugar-sweetened soft drinks, diet soft drinks, and serum uric acid level: the Third National Health and Nutrition Examination Survey. Arthritis Rheum 2008;59:109-116.

53 He FJ, Marrero NM, MacGregor GA: Salt intake is related to soft drink consumption in children and adolescents: a link to obesity? Hypertension 2008;51:629-634.

54 Palmer JR, Boggs DA, Krishnan S, Hu FB, Singer M, Rosenberg L: Sugar-sweetened beverages and incidence of type 2 diabetes mellitus in African American women. Arch Intern Med 2008;168:1487-1492.

55 Assy N, Nasser G, Kamayse I, Nseir W, Beniashvili Z, Djibre A, Grosovski M: Soft drink consumption linked with fatty liver in the absence of traditional risk factors. Can J Gastroenterol 2008;22:811-816. 


\section{CardioRenal Medicine}

\begin{tabular}{l|l}
\hline \multicolumn{2}{l}{ Cardiorenal Med 2011;1:5-12 } \\
\hline $\begin{array}{l}\text { DOI: 10.1159/000322822 } \\
\text { Published online: January 17, } 2011\end{array}$ & $\begin{array}{l}\text { @ } 2011 \text { S. Karger AG, Basel } \\
\text { www.karger.com/crm }\end{array}$ \\
\hline
\end{tabular}

Sowers et al.: Obesity and Chronic Kidney Disease

-56 WRITING GROUP MEMBERS, Lloyd-Jones D, Adams RJ, Brown TM, Carnethon M, Dai S, De Simone G, Ferguson TB, Ford E, Furie K, Gillespie C, Go A, Greenlund K, Haase N, Hailpern S, Ho PM, Howard V, Kissela B, Kittner S, Lackland D, Lisabeth L, Marelli A, McDermott MM, Meigs J, Mozaffarian D, Mussolino M, Nichol G, Roger VL, Rosamond W, Sacco R, Sorlie P, Roger VL, Thom T, Wasserthiel-Smoller S, Wong ND, Wylie-Rosett J, American Heart Association Statistics Committee and Stroke Statistics Subcommittee: Heart disease and stroke statistics - 2010 update: a report from the American Heart Association. Circulation 2010;121:e46-e215.

57 Owan TE, Hodge DO, Herges RM, Jacobsen SJ, Roger VL, Redfield MM: Trends in prevalence and outcome of heart failure with preserved ejection fraction. N Engl J Med 2006;355:251-259.

58 Alpert MA, Lambert CR, Terry BE, Cohen MV, Mukerji V, Massey CV, Hashimi MW, Panayiotou H: Interrelationship of left ventricular mass, systolic function and diastolic filling in normotensive morbidly obese patients. Int J Obes Relat Metab Disord 1995;19:550-557.

59 Lauer MS, Anderson KM, Kannel WB, Levy D: The impact of obesity on left ventricular mass and geometry. The Framingham Heart Study. JAMA 1991;266:231-236.

60 Zhou X, Ma L, Habibi J, Whaley-Connell A, Hayden MR, Tilmon RD, Brown AN, Kim JA, Demarco VG, Sowers JR: Nebivolol improves diastolic dysfunction and myocardial remodeling through reductions in oxidative stress in the Zucker obese rat. Hypertension 2010;55:880-888.

61 Nishimura RA, Tajik AJ: Evaluation of diastolic filling of left ventricle in health and disease: Doppler echocardiography is the clinician's Rosetta Stone. J Am Coll Cardiol 1997;30:8-18.

62 Sawyer DB, Siwik DA, Xiao L, Pimentel DR, Singh K, Colucci WS: Role of oxidative stress in myocardial hypertrophy and failure. J Mol Cell Cardiol 2002;34:379-388.

63 Sorescu D, Griendling KK: Reactive oxygen species, mitochondria, and NAD(P)H oxidases in the development and progression of heart failure. Congest Heart Fail 2002;8:132-140.

64 Takimoto E, Kass DA: Role of oxidative stress in cardiac hypertrophy and remodeling. Hypertension 2007;49:241-248.

65 Ritchie RH, Delbridge LM: Cardiac hypertrophy, substrate utilization and metabolic remodelling: cause or effect? Clin Exp Pharmacol Physiol 2006;33:159-166.

66 Russo I, Del Messe P, Doronzo G, Mattiello L, Viretto M, Bosia A, Anfossi G, Trovati M: Resistance to the nitric oxide/ cyclic guanosine 5'-monophosphate/protein kinase G pathway in vascular smooth muscle cells from the obese Zucker rat, a classical animal model of insulin resistance: role of oxidative stress. Endocrinology 2008;149:1480-1489.

-67 Massion PB, Dessy C, Desjardins F, Pelat M, Havaux X, Belge C, Moulin P, Guiot Y, Feron O, Janssens S, Balligand JL: Cardiomyocyte-restricted overexpression of endothelial nitric oxide synthase (NOS3) attenuates beta-adrenergic stimulation and reinforces vagal inhibition of cardiac contraction. Circulation 2004;110:2666-2672.

-68 Whaley-Connell A, Govindarajan G, Habibi J, Hayden MR, Cooper SA, Wei Y, Ma L, Qazi M, Link D, Karuparthi PR, Stump CS, Ferrario CM, Sowers JR: Angiotensin-II mediated oxidative stress promotes myocardial tissue remodeling in the transgenic TG (mRen2) 27 Ren2 rat. Am J Physiol Endocrinol Metab 2007;293:E355-E363.

69 Kobayasi R, Akamine EH, Davel AP, Rodrigues MA, Carvalho CR, Rossoni LV: Oxidative stress and inflammatory mediators contribute to endothelial dysfunction in high-fat diet-induced obesity in mice. J Hypertens 2010;28:21112119.

70 House AA, Haapio M, Lassus J, Bellomo R, Ronco C: Therapeutic strategies for heart failure in cardiorenal syndromes. Am J Kidney Dis 2010;56:759-773. 